\title{
HYDROSTATIC PRESSURE ACTS TO STABILISE A CHONDROGENIC PHENOTYPE IN PORCINE JOINT TISSUE DERIVED STEM CELLS
}

\author{
Tatiana Vinardell ${ }^{1,3}$, Rebecca A. Rolfe ${ }^{1,2}$, Conor T. Buckley ${ }^{1,3}$, Eric G. Meyer ${ }^{1,3}$, Mark Ahearne ${ }^{1,3}$, \\ Paula Murphy ${ }^{1,2}$ and Daniel J. Kelly $1,3 *$
}

\begin{abstract}
${ }^{1}$ Trinity Centre for Bioengineering, Trinity Biomedical Sciences Institute, Trinity College Dublin, Ireland
${ }^{2}$ Department of Zoology, School of Natural Sciences, Trinity College Dublin, Ireland

${ }^{3}$ Department of Mechanical and Manufacturing, School of Engineering, Trinity College Dublin, Ireland
\end{abstract}

\begin{abstract}
Hydrostatic pressure (HP) is a key component of the in vivo joint environment and has been shown to enhance chondrogenesis of stem cells. The objective of this study was to investigate the interaction between HP and TGF- $\beta 3$ on both the initiation and maintenance of a chondrogenic phenotype for joint tissue derived stem cells. Pellets generated from porcine chondrocytes (CCs), synovial membrane derived stem cells (SDSCs) and infrapatellar fat pad derived stem cells (FPSCs) were subjected to 10 MPa of cyclic HP (4 h/day) and different concentrations of TGF- $\beta 3(0,1$ and $10 \mathrm{ng} / \mathrm{mL})$ for 14 days. CCs and stem cells were observed to respond differentially to both HP and TGF- $\beta 3$ stimulation. HP in the absence of TGF- $\beta 3$ did not induce robust chondrogenic differentiation of stem cells. At low concentrations of TGF- $\beta 3(1 \mathrm{ng} / \mathrm{mL})$, HP acted to enhance chondrogenesis of both SDSCs and FPSCs, as evident by a 3 -fold increase in $50 x 9$ expression and a significant increase in glycosaminoglycan accumulation. In contrast, HP had no effect on cartilage-specific matrix synthesis at higher concentrations of TGF- $\beta 3(10 \mathrm{ng} / \mathrm{mL})$. Critically, HP appears to play a key role in the maintenance of a chondrogenic phenotype, as evident by a downregulation of the hypertrophic markers type X collagen and Indian hedgehog in SDSCs irrespective of the cytokine concentration. In the context of stem cell based therapies for cartilage repair, this study demonstrates the importance of considering how joint specific environmental factors interact to regulate not only the initiation of chondrogenesis, but also the development of a stable hyaline-like repair tissue.
\end{abstract}

Keywords: Hydrostatic pressure, cartilage, synovial membrane, infrapatellar fat pad, transforming growth factor (TGF)- $\beta 3$, stem cells, chondrocytes.

\footnotetext{
*Address for correspondence:

Daniel J. Kelly

Trinity Centre for Bioengineering, School of Engineering Trinity College Dublin, Dublin 2

Ireland
}

Telephone Number: +353-1-896-3947

Fax Number: +353-1-679-5554

E-mail: kellyd9@tcd.ie

\section{Introduction}

Articular cartilage lesions do not heal adequately, leading to intense effort towards developing new therapies to repair and regenerate articular cartilage (Buckwalter, 1998; Elder and Athanasiou, 2009). The variety of treatment options available implies that there is no single, ideal, reliable and predictable therapy (Hildner et al., 2011). The use of mesenchymal stem cells (MSCs) as part of a cell based therapy for cartilage repair is very appealing. MSCs have a high potential for proliferation and differentiation (Pittenger et al., 1999) and overcome many of the drawbacks associated with the use of autologous chondrocytes (CCs), including the creation of a new defect in the articular surface. Stem cells isolated from synovial joint tissues such as synovial membrane (SM) (De Bari et al., 2001; Pei et al., 2008a; Pei et al., 2008b) and infrapatellar fat pad (FP) (Dragoo et al., 2003; Wickham et al., 2003; English et al., 2007; Khan et al., 2007; Khan et al., 2008) are a particularly promising alternative to CCs as they are phenotypically similar to CCs and accessible during arthroscopy (Segawa et al., 2009). This has led to increased interest in using joint tissue derived stem cells for engineering functional cartilaginous grafts (Buckley et al., 2010a; Buckley et al., 2010b; Vinardell et al., 2010). To fully realise their potential, in this regard, requires a more thorough understanding of how biochemical and biophysical factors will influence their phenotypic stability and biosynthetic activities during in vitro cultivation and following implantation into the joint environment.

The pellet culture model is commonly used to explore chondrogenic differentiation of MSCs (Johnstone et al., 1998). In this system, cell-cell interactions within the MSC condensation coupled with the extrinsic signal provided by the addition of transforming growth factor beta 1 (TGF- $\beta 1$ ) has been shown to induce chondrogenesis of MSCs. Chondrogenesis was found to be dependent on the concentration of TGF- $\beta 1$ within the culture media, with more robust differentiation observed at higher concentrations of TGF- $\beta 1$ (Johnstone et al., 1998). Chondrogenesis of synovial membrane derived stem cells (SDSCs) and infrapatellar fat pad derived stem cells (FPSCs) has also been demonstrated using the pellet culture system (Mochizuki et al., 2006; Marsano et al., 2007; Vinardell et al., 2010). Additional growth factors have been used in combination with TGF- $\beta$ stimulation with synergistic effects observed (Lee et al., 2008; Pei et al., 2008b). While cellular condensation coupled with endogenous TGF- $\beta$ stimulation have been shown to induce chondrogenic differentiation in vitro, other environmental 
signals, including biophysical stimuli, will play a key role in determining stem cell fate.

Biophysical stimuli such as tension, compression, fluid flow and hydrostatic pressure (HP) are thought to regulate chondrogenesis of stem cells (Stoddart et al., 2009; Kelly and Jacobs, 2010). Finite element models have been used to support the hypothesis that mechanical loading can regulate tissue differentiation and that HP can promote cartilage formation and potentially suppress endochondral ossification (Carter et al., 1998; Loboa et al., 2001). In vitro studies have demonstrated that physiological frequencies and magnitudes of HP ( 3 to $10 \mathrm{MPa}$ at frequencies of 1 $\mathrm{Hz}$ ) increase CCs matrix synthesis (Parkkinen et al., 1993; Toyoda et al., 2003a; Toyoda et al., 2003b; Elder et al., 2006; Elder and Athanasiou, 2008; Elder and Athanasiou, 2009). In either the absence or presence of TGF, cyclic HP also seems to enhance chondrogenesis of bone marrow MSCs at the gene and/or protein level (Angele et al., 2003; Miyanishi et al., 2006b; Finger et al., 2007; Elder and Athanasiou, 2008; Wagner et al., 2008; Meyer et al., 2011). HP has also been shown to enhance chondrogenesis of SDSCs (Sakao et al., 2008; Wu et al., 2008), however the interaction between HP and members of the TGF- $\beta$ family of growth factors in regulating the initiation and maintenance of a chondrogenic phenotype in joint tissue derived stem cells remains poorly understood.

MSCs offer tremendous potential for the treatment of damaged and diseased articular cartilage. The success of new therapies utilising joint tissue derived stem cells will require a fundamental understanding of how local environmental factors regulate their phenotype and subsequent synthetic activities. While both TGF- $\beta$ stimulation and hydrostatic pressure have been identified as key determinants of stem cell differentiation, little is known about how these signals interact to regulate their fate. Given that both stimuli are key components of the regenerative environment, the goal of this study was to investigate the interaction between HP and TGF- $\beta 3$ in regulating the induction and maintenance of a chondrogenic phenotype in joint tissue derived stem cells. To this end, this study explored the combined effects of HP and different concentrations of TGF- $\beta 3(0,1$ and $10 \mathrm{ng} /$ $\mathrm{mL}$ ) on chondrogenic gene expression and matrix synthesis for SDSCs and FPSCs and compared this response to CCs isolated from articular cartilage from the same joint. Given that retrieving stem cells from multiple tissues in healthy humans is challenging, a porcine model was chosen to address this research question. Pigs are similar to humans in terms of their genetics, anatomy and physiology (Vacanti et al., 2005), and the tripotentiality of porcine MSCs from FPSCs and SDSCs has been demonstrated in previous studies (Pei et al., 2008b; Vinardell et al., 2010).

\section{Materials and Methods}

\section{Cell isolation and expansion}

CCs and joint tissue derived stem cells were aseptically harvested from the femoropatellar joint of four month old pigs (two donors). Cartilage tissue harvested from the tibial, patellar and femoral surface were pooled for each pig in order to obtain sufficient numbers of CCs to perform the study. Briefly, full depth articular cartilage slices were rinsed with phosphate buffered saline (PBS) containing penicillin/streptomycin $(200 \mathrm{U} / \mathrm{mL})(\mathrm{GIBCO}$, Biosciences, Dublin, Ireland). The cartilage slices were then combined and digested with DMEM GlutaMAX (GIBCO) containing collagenase type II $(315 \mathrm{U} / \mathrm{mg})$ (Worthington, Langanbach Services, Bray, Ireland) and amphotericin B $(2.5 \mu \mathrm{g} / \mathrm{mL})$ (Sigma-Aldrich, Dublin, Ireland) for $16-18 \mathrm{~h}$ under constant rotation at $37^{\circ} \mathrm{C}$. The resulting cell suspension was then filtered through a $40 \mu \mathrm{m}$ pore-size cell sieve (Falcon, Sarstedt, Wexford, Ireland) and the filtrate centrifuged and rinsed with PBS twice. SM and FP tissues were harvested, sliced and rinsed with PBS (Sigma-Aldrich) containing penicillin/streptomycin (200 U/mL) and amphotericin B $(2.5 \mu \mathrm{g} / \mathrm{mL})$. SM and FP pieces were incubated with DMEM GlutaMAX containing collagenase type II (315 U/mg) for 3-4 h under constant rotation at $37^{\circ} \mathrm{C}$. The resulting cell suspension was then filtered through a $40 \mu \mathrm{m}$ pore-size cell sieve and the filtrate centrifuged and rinsed with PBS twice. CCs, SDSCs and FPSCs were seeded at a density of $5 \times 10^{3} \mathrm{cells} / \mathrm{cm}^{2}$ in 175 $\mathrm{cm}^{2} \mathrm{~T}$-flasks in a humidified atmosphere at $37^{\circ} \mathrm{C}$ and $5 \%$ $\mathrm{CO}_{2}$ and expanded to passage one for $\mathrm{CCs}$ (approximately 7 population doublings) and to passage two for the stem cells (approximately 14-15 population doublings). Cells were also cryopreserved for replicate studies (hgDMEM supplemented with $10 \% \mathrm{v} / \mathrm{v}$ foetal bovine serum (Gibco; FBS) and $10 \%$ dimethylsulphoxide (Sigma-Aldrich; DMSO) in a liquid nitrogen tank). Viable cells were counted using a haemocytometer and $0.4 \%$ trypan blue staining. Isolated cells from different tissues were maintained in DMEM GlutaMAX supplemented with 10 $\% \mathrm{v} / \mathrm{v}$ foetal bovine serum (FBS) (Gibco) and $100 \mathrm{U} / \mathrm{mL}$ penicillin/streptomycin during the monolayer expansion phase with $5 \mathrm{ng} / \mathrm{mL}$ of human fibroblast growth factor-2 (FGF-2) (Prospec, Ness-Ziona, Israel).

\section{Pellet formation}

250000 cells were placed in $1.5 \mathrm{~mL}$ conical microtubes and centrifuged at $650 \mathrm{G}$ for $5 \mathrm{~min}$. The pellets were cultured in a chemically defined chondrogenic medium: DMEM GlutaMAX supplemented with $100 \mathrm{U} / \mathrm{mL}$ penicillin/ streptomycin, $100 \mu \mathrm{g} / \mathrm{mL}$ sodium pyruvate, $40 \mu \mathrm{g} / \mathrm{mL}$ L-proline, $50 \mu \mathrm{g} / \mathrm{mL}$ L-ascorbic acid-2-phosphate, $4.7 \mu \mathrm{g} /$ $\mathrm{mL}$ linoleic acid, $1.5 \mathrm{mg} / \mathrm{mL}$ bovine serum albumin (BSA), $1 \times$ insulin-transferrin-selenium, $100 \mathrm{nM}$ dexamethasone (all from Sigma-Aldrich). The pellets were cultured with different concentrations of human TGF- $\beta 3$ (Prospec) 0,1 and $10 \mathrm{ng} / \mathrm{mL}$. Medium was exchanged every 3 or 4 days with $1 \mathrm{~mL}$ samples of media taken for biochemical analysis.

\section{Application of hydrostatic pressure}

Pellets were subjected to HP after an initial $24 \mathrm{~h}$ of free swelling culture HP (10-12 per group). Pellets were sealed in sterile plastic bags with $4 \mathrm{~mL}$ of chondrogenic medium with different concentrations of TGF- $\beta 3$ and assigned to receive either mechanical stimulation (HP group), or were left unloaded (Free swelling: FS group). The loaded group was exposed to $10 \mathrm{MPa}$ of $\mathrm{HP}$ at a frequency of $1 \mathrm{~Hz}$ for $4 \mathrm{~h}$ per day, for 14 days, while the unloaded controls were kept 
in bags in an incubator immersed in water at $37^{\circ} \mathrm{C}$ during the loading period. After loading, all pellets were returned to culture dishes. A stainless steel pressure chamber (Parr Instruments Company, Moline, IL, USA), connected to a piston (phd Inc., Irish Pneumatics, Kildare, Ireland), driven by an Instron 8801 materials testing machine was used to generate the required levels of HP. Further details are available elsewhere (Meyer et al., 2011).

\section{Histology and immunohistochemistry}

For histological evaluation pellets were fixed in $4 \%$ paraformaldehyde and embedded in paraffin, cut into 5 $\mu \mathrm{m}$ thick sections, and stained with $1 \%$ alcian blue $8 \mathrm{GX}$ (Sigma-Aldrich) in $0.1 \mathrm{M} \mathrm{HCl}$ to assess glycosaminoglycan content and picrosirius red to detect collagen. Type I, II and $\mathrm{X}$ collagen content were evaluated with a standard immunohistochemical technique; briefly, sections were treated with peroxidase (between steps, slides were washed in PBS) followed by treatment with chondroitinase ABC (Sigma-Aldrich) in a humidified environment at $37^{\circ} \mathrm{C}$ to enhance permeability of the extracellular matrix. After incubation with goat serum to block non-specific sites, the collagen type I (ab6308, 1:400; $5.7 \mathrm{mg} / \mathrm{mL})$, collagen type II (ab3092,1:100; $1 \mathrm{mg} / \mathrm{mL})$ or collagen type $\mathrm{X}$ (ab49945,1:200; $1.4 \mathrm{mg} / \mathrm{mL}$ ) primary antibody (mouse monoclonal, Abcam, Cambridge, UK) was applied on the sections for $1 \mathrm{~h}$ at room temperature. Next, the secondary antibody (Anti-Mouse IgG biotin conjugate (1:200; 2.1 $\mathrm{mg} / \mathrm{mL}$ ), Sigma-Aldrich) was added for $1 \mathrm{~h}$, followed by incubation with ABC reagent (Vectastain PK-4000, Vector Labs, Peterborough, UK) for $45 \mathrm{~min}$. Finally, the slides were developed with DAB peroxidase (Vector Labs) for 5 min. Positive and negative controls were included in the immunohistochemistry staining protocol for each batch.

\section{Biochemical analysis}

All samples were digested in papain $(125 \mu \mathrm{g} / \mathrm{mL})$ in 0.1 $\mathrm{M}$ sodium acetate, $5 \mathrm{mM}$ cysteine $\mathrm{HCl}, 0.05 \mathrm{M}$ EDTA, $\mathrm{pH} 6.0$ (all from Sigma-Aldrich) at $60{ }^{\circ} \mathrm{C}$ under constant rotation for $18 \mathrm{~h}$. Aliquots of the digested samples were assayed separately for DNA, collagen and sulphated glycosaminoglycan (sGAG) content. DNA content was quantified using the Quant-it Picogreen DNA assay (Invitrogen, Paisley, UK). The proteoglycan content was estimated by quantifying the amount of sGAG in constructs using the dimethylmethylene blue dye-binding assay (Blyscan, Biocolor, Carrickfergus, Northern Ireland), with a chondroitin sulphate standard. Total collagen content was determined by measuring the hydroxyproline content, using a hydroxyproline-to-collagen ratio of 1:7.69 (Kafienah and Sims, 2004; Ignat'eva et al., 2007). Alkaline phosphatase activity was determined using SensoLyte ${ }^{\circledR}$ pNPP Alkaline Phosphatase Assay Colorimetric kit (AnaSpec, San Jose, CA, USA) and the absorbance was measured at $405 \mathrm{~nm}$. At each media exchange, samples of media were taken for analysis of alkaline phosphatase activity, sGAG and total collagen secreted into the media. The total release to the media over the 14 day culture period for all pellets in each experimental group was measured and from this the average release per pellet was determined. The concentration of TGF- $\beta 1$ in the culture media was quantified using a TGF- $\beta 1$ ELISA kit (Booster Immunoleader, Wuhan, China) following the manufacturer's instructions. The concentration of TGF- $\beta 3$ in the media was quantified using a DuoSet ELISA Development System (R\&D Systems, Abingdon, UK) following the manufacturer's protocol.

\section{RNA isolation and quantitative real-time polymerase chain reaction}

Quantitative real-time reverse transcription-polymerase chain reaction (qRT-PCR) was used to determine the relative gene expression changes in chondrogenic specific genes over time and subsequent to the application of loading. Total RNA was extracted from SDSCs and FPSCs pellets following 14 days of culture. Day zero groups were harvested following centrifugation and formation of cellular pellets. Loaded and unloaded groups were harvested directly after the application of loading at day 14. Pellet construct pooling was performed for all groups, with a total of 5 pellets pooled per group. Total cellular RNA was extracted from each pellet group by physical homogenisation using a motor driven pestle and mortar system (Sigma-Aldrich) in $1 \mathrm{~mL}$ of TRIZOL reagent (Invitrogen), followed by a chloroform (Sigma-Aldrich) extraction with PureLink ${ }^{\text {TM }}$ RNA Mini kit (Invitrogen) as per manufacturer's instructions. RNA was re-suspended in RNase free water prior to reverse transcription.

Total RNA concentrations were determined using the Quant-iT TM RNA assay and a Qubit ${ }^{\circledR}$ fluorometer (Invitrogen) and adjusted to a standard concentration prior to cDNA synthesis. To quantify mRNA expression, $100 \mathrm{ng}$ of total RNA was reverse transcribed into cDNA using iScript ${ }^{\mathrm{TM}}$ cDNA systhesis kit (BioRad, Hemel Hempstead, UK) as per manufacturer's instructions. TaqMan ${ }^{\circledR}$ gene expression Assays (Applied Biosystems/ Life Technologies, Paisley, UK) which contain forward and reverse primers, and a FAM-labelled TaqMan probe for porcine (Sus scrofa) Sox9 (Ss03392406m1), aggrecan (Ss03374822m1), collagen type I alpha I(Ss03373340m1), collagen type II alpha 1 (Ss03373344g1), collagen type X alpha 1 (Ss03391766m1), TGF- $\beta$ receptor 3 (Ss03394536m1), Indian Hedgehog (Ss03373541m1) and Glyceraldehyde-three-phosphate dehydrogenase (GAPDH) (Ss03373286u1) were used in this study. Each assay was chosen based on the amplicon spanning an exon junction. qRT-PCR was performed using an ABI 7500 Sequence Detection system (Applied Biosystems). A $20 \mu \mathrm{L}$ volume was added to each well $(5 \mu \mathrm{L}$ of cDNA preparation diluted 1:5 with RNase free water, $1 \mu \mathrm{L}$ of gene assay, $10 \mu \mathrm{L}$ of TaqMan Universal PCR Master mix (Applied Biosystems) and $4 \mu \mathrm{L}$ RNase free water). Samples were assayed in triplicate in one run (40 cycles). qRT-PCR data were analysed using relative quantification and the Delta $C^{\mathrm{t}}$-method as described previously (Livak and Schmittgen, 2001) with the FS day zero samples used as the calibrator and GAPDH as the endogenous control gene. Relative quantification values are presented as fold changes in gene expression plus/minus the standard error of the mean relative to the control group, which was normalised to one. 


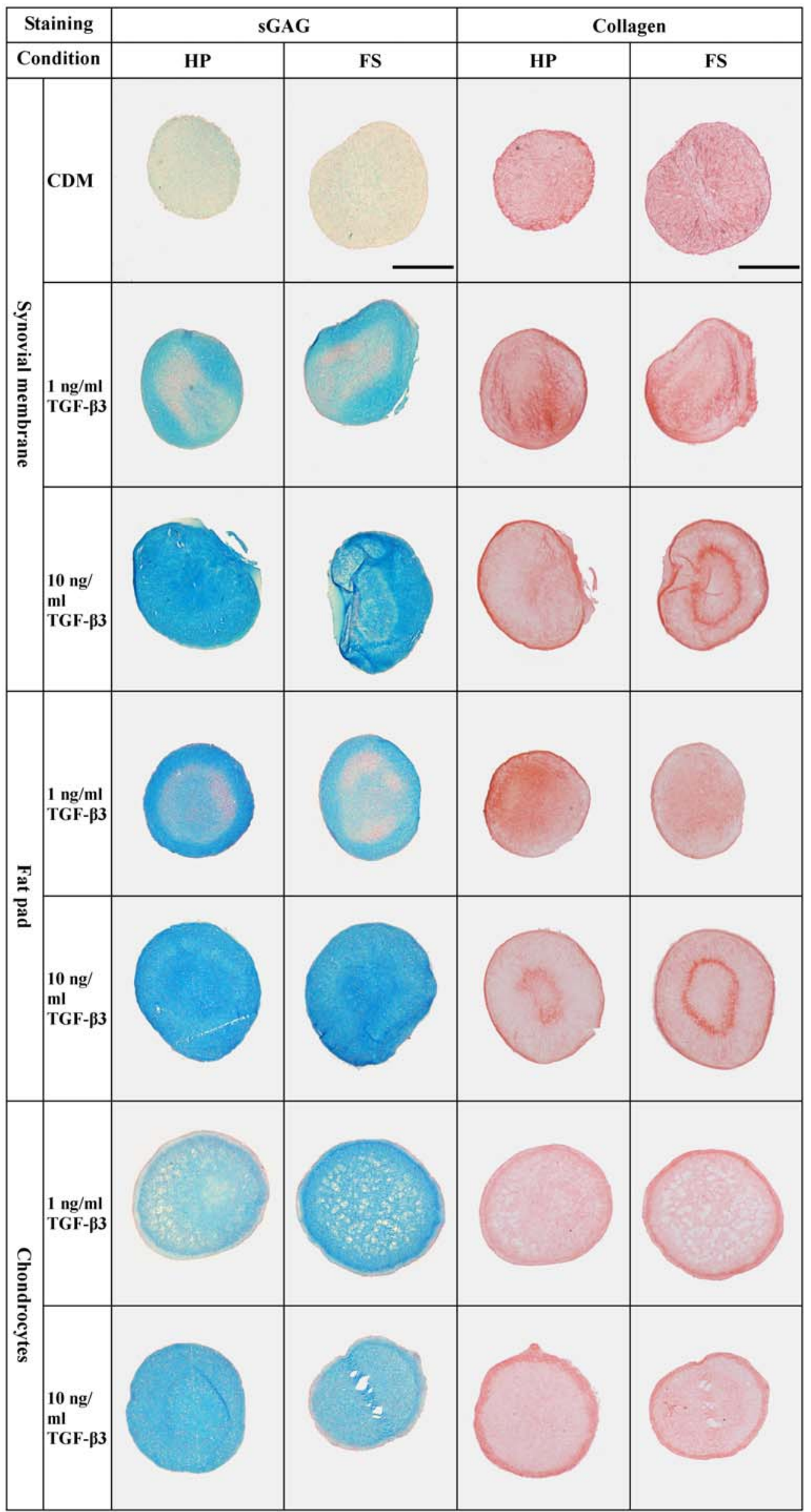

Fig. 1. Histology sections of synovial membrane, fat pad and chondrocytes pellets kept in free swelling conditions (FS) or exposed to hydrostatic pressure (HP) following 14 days of culture. Pellets were stained with alcian blue (stains sulphated glycosaminoglycan, left columns) and picro-sirius red (stains collagen, right columns); scale bar $500 \mu \mathrm{m}$. 


\begin{tabular}{|r|c|c|c|c|c|c|}
\hline \multicolumn{2}{|c|}{ Type II collagen } & \multicolumn{2}{c|}{ Type X collagen } & \multicolumn{2}{c|}{ Type I collagen } \\
\hline & $10 \mathrm{ng} / \mathrm{ml}$ & $1 \mathrm{ng} / \mathrm{ml}$ & $10 \mathrm{ng} / \mathrm{ml}$ & $1 \mathrm{ng} / \mathrm{ml}$ & $10 \mathrm{ng} / \mathrm{ml}$ \\
\hline & & & & & \\
\hline & & & & & \\
\hline & & & & & \\
\hline & & & & & \\
\hline & & & & & \\
\hline & & & & & \\
\hline \\
\hline
\end{tabular}

Fig. 2. Synovial membrane pellets immunostained for type II, X and I collagen with subsequent controls (Type II collagen, positive control: cartilage, negative control: ligament; type X collagen, positive control: growth plate, negative control: cartilage; type I collagen positive control: ligament, negative control: cartilage). Images are taken from regions of the pellets that stained positive for picro-sirius red. Scale bar $100 \mu \mathrm{m}$.

\section{Statistical analysis}

For each cell source, at least two replicates of the entire study were performed using cells from the same donor. For each of these replicates, twelve samples were analysed per group at each time point, with 5 samples used for biochemical analysis of matrix components, 5 pooled samples for qRT-PCR and 2 samples were used for histology. In addition, the average sGAG and collagen release to the media per pellet in each experimental group, as well as the concentration of TGF- $\beta 1$ and TGF- $\beta 3$ in the media, was determined for each replicate of the experiment. The data from all replicates was then pooled for subsequent statistical analysis. Differences in gene expression, mechanical and biochemical properties with cell type and/or time-in-culture were determined by $t$-tests and by analysis of variance with time or loading as independent factors, followed by Tukey's post-hoc test (95\% confidence Interval). Statistics were preformed with MINITAB 15.1 (Minitab, Coventry, UK) and the GraphPadPrism 4 software package (San Diego, CA, USA). Data are expressed in the form of mean \pm standard error of the mean (SEM). Statistical significance was declared at $p \leq 0.05$. Given the unexpected response of chondrocytes to different concentrations of TGF- $\beta 3$ (see data below) we replicated this arm of the study using cells derived from a different donor and observed the same response.

\section{Results}

\section{Effect of HP on pellet morphology}

After 14 days in culture, pellets were mostly spherical and stained positive for proteoglycan and collagen deposition when supplemented with TGF- $\beta 3$, while minimum staining was observed in both the non-supplemented FS and HP groups (Fig. 1). In general, an increase in matrix staining was observed for FPSCs and SDSCs when supplemented with higher concentrations of TGF- $\beta 3$. Moreover, HP appeared to influence the organisation of the neo-tissue, with a more obvious core region in the FS SDSC pellets supplemented with $10 \mathrm{ng} / \mathrm{mL}$ of TGF- $\beta 3$ compared to a more homogeneous distribution of extracellular matrix in the HP group (Fig. 1). CCs pellets supplemented with $1 \mathrm{ng} / \mathrm{mL}$ of TGF- $\beta 3$ presented some evidence of cell clustering, with more intense staining observed in the FS group in comparison with pellets subjected to HP. Immunohistochemistry confirmed the presence of type II collagen in the SDSCs pellets (Fig. 2). The same pattern of staining was observed in FPSCS and CCs pellets (data not shown). Weak staining for type I and X collagen was observed.

\section{Effect of HP on matrix production}

HP had no effect on DNA content for any cell type at 0,1 and $10 \mathrm{ng} / \mathrm{mL}$ of TGF- $\beta 3$ (data not shown). HP significantly increased sGAG accumulation for both FPSCs and SDSCs supplemented with $1 \mathrm{ng} / \mathrm{mL}$ of TGF- $\beta 3$ (FPSCs HP: 10.5 $\mu \mathrm{g}( \pm 1.1) v s$. FPSCs FS: $7.01 \mu \mathrm{g}( \pm 0.6)$; SDSCs HP: $8.35 \mu \mathrm{g}( \pm 1.3) v s$. SDSCs FS: $5.5 \mu \mathrm{g}( \pm 0.5))$, but did not affect collagen synthesis (Fig. 3a). In contrast, HP had no effect on sGAG synthesis for both FPSCs and SDSCs when supplemented with $10 \mathrm{ng} / \mathrm{mL}$ of TGF- $\beta 3$ (Fig. 3b). For the CCs pellets, HP decreased sGAG accumulation when supplemented with $1 \mathrm{ng} / \mathrm{mL}$ of TGF- $\beta 3$ (FS: $27.7 \mu \mathrm{g}$ ( \pm 2.3$)$ vs. HP: $14.3 \mu \mathrm{g}( \pm 1.7)$ ) (Fig. 3a). A similar result was observed for the total amount of sGAG synthesised (addition of sGAG retained in the pellet and the amount of sGAG secreted to the media). HP was also observed to inhibit collagen accumulation for CCs when supplemented 

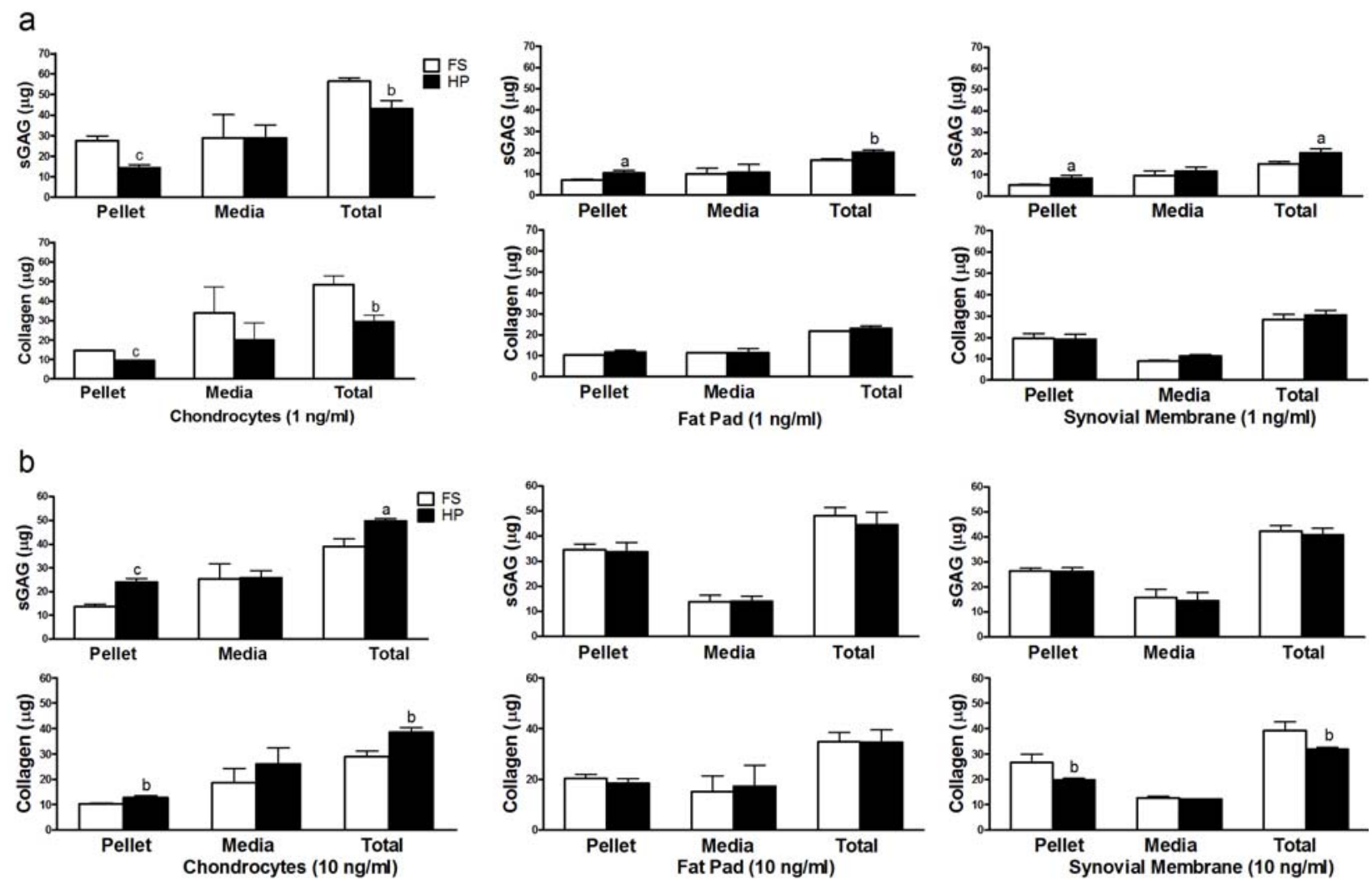

Fig. 3. Sulphated glycosaminoglycan (sGAG) and collagen content measured in the pellets and culture media of chondrocytes and joint tissue derived stem cells with (a) $1 \mathrm{ng} / \mathrm{mL}$ of TGF- $\beta 3$ or (b) $10 \mathrm{ng} / \mathrm{mL}$ of TGF- $\beta 3$. Free swelling (FS); hydrostatic pressure (HP). Media values represent the total amount of matrix components released per pellet over the entire culture period. The total content represents the sum of matrix components being retained in each pellet and released to the media. a: $p<0.05$; b: $p<0.001$; $\mathrm{c}: p<0.0001$.

a

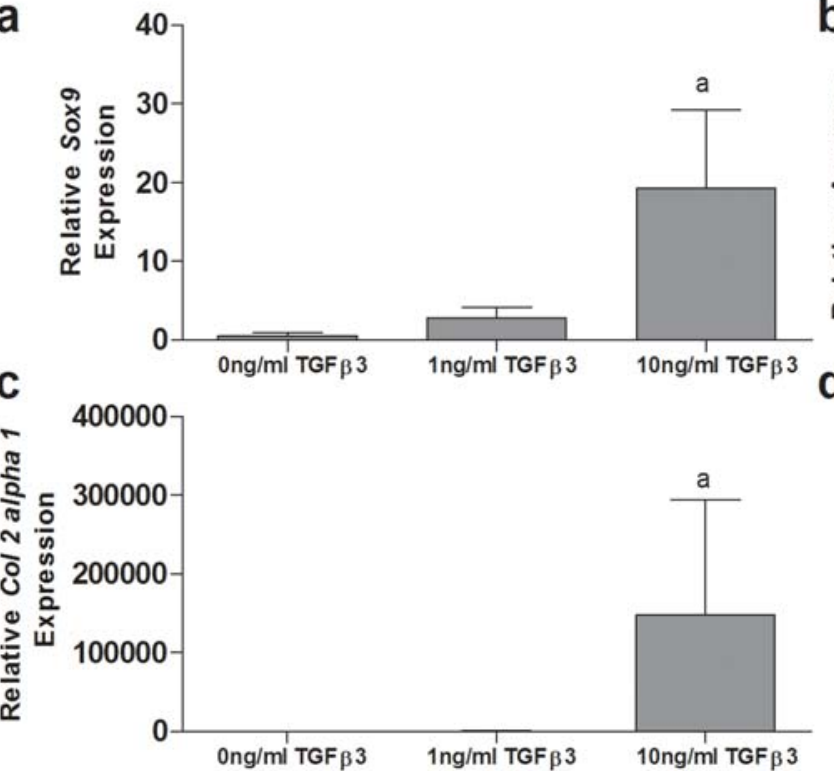

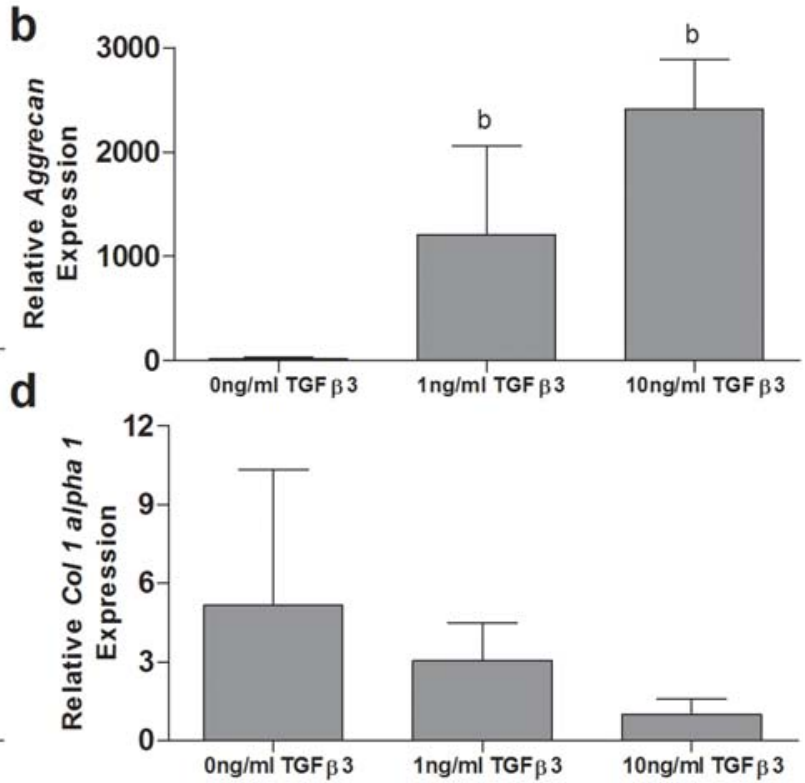

Fig. 4. Chondrogenic and extracellular matrix-specific relative gene expression in synovial membrane pellets cultured in free swelling conditions with 0,1 or $10 \mathrm{ng} / \mathrm{mL}$ TGF- $\beta 3$ over 14 days. Calibration performed according to expression of the endogenous control gene GAPDH and normalised to day 0 free swelling controls. Sox9 (a), Aggrecan (b), Collagen type II alpha 1 (c) and Collagen type I alpha 1 (d) expression. Data is expressed as relative expression per group and represented as mean \pm SEM. Pellets were analysed from 3 independent experimental replicates, using 5 pellets pooled from each replicate. a: $p<0.05$, b: $p<0.0001 v s$. gene expression at day 0 . 
a

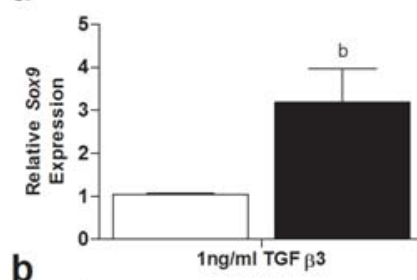

b

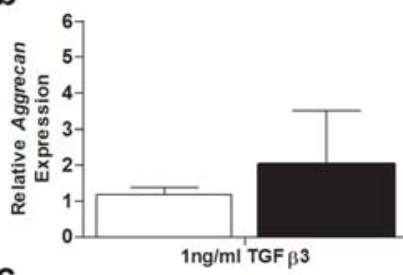

C

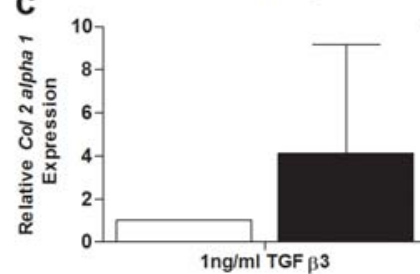

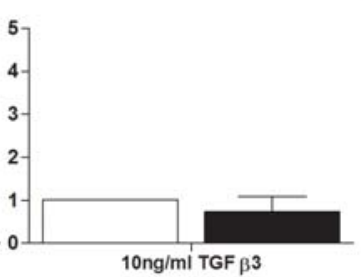
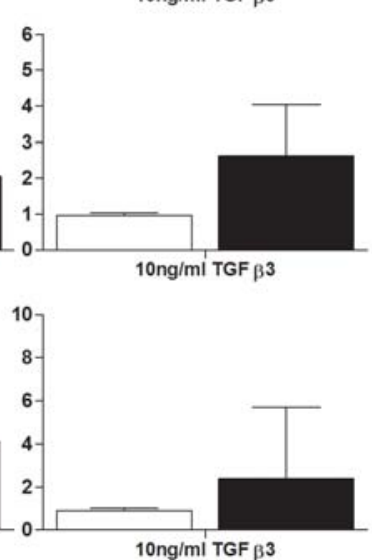

d

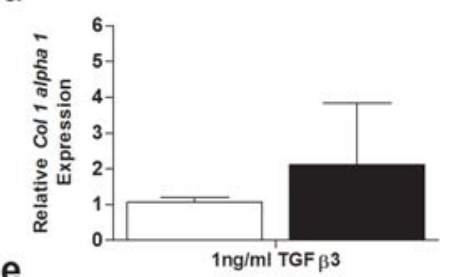

e.

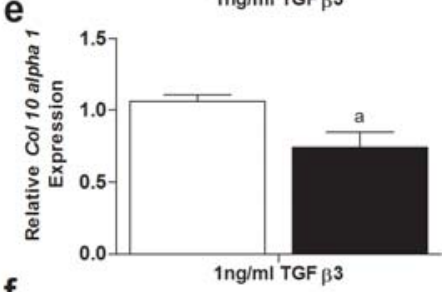

f

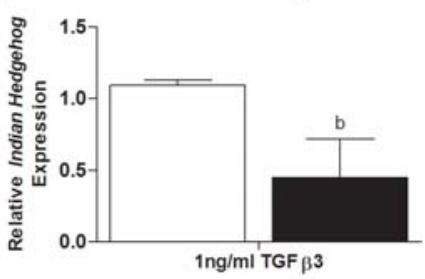

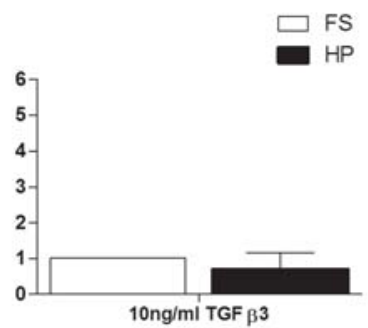
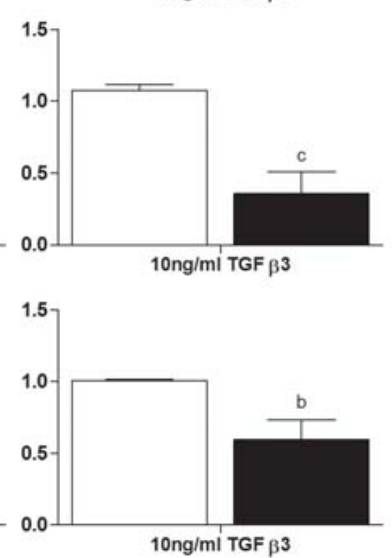

Fig. 5. The influence of hydrostatic pressure on gene expression in synovial membrane pellets at day 14 cultured in free swelling (FS) and hydrostatic pressure (HP) conditions with 1 or $10 \mathrm{ng} / \mathrm{mL}$ TGF- $\beta 3$. Calibration of each gene to GAPDH expression levels and normalised to free swelling controls. Sox9 (a), Aggrecan (b), Collagen type II alpha 1 (c), Collagen type I alpha 1 (d), Collagen type X alpha 1 (e) and Indian Hedgehog (Ihh) (f) expression. Data is expressed as relative expression per group and represent mean \pm SEM. Pellets were analysed from 3 independent experimental replicates, using 5 pellets pooled from each replicate. a: $p<0.1$, b: $p<0.05$, c: $p<0.01$. vs. gene expression at day 14 for FS control.

with $1 \mathrm{ng} / \mathrm{mL}$ of TGF- $\beta 3$ (FS: $14.8 \mu \mathrm{g}( \pm 0.25) v s$. HP: 9.34 $\mu \mathrm{g}( \pm 0.05))$ (Fig. 3a). When CCs were supplemented with $10 \mathrm{ng} / \mathrm{mL}$ of TGF- $\beta 3$, HP increased both SGAG (FS: 13.7 $\mu \mathrm{g}( \pm 1.1) v s$. HP: $23.9 \mu \mathrm{g}( \pm 1.6))$ and collagen (FS: 10.1 $\mu \mathrm{g}( \pm 0.4) v s$. HP: $12.8 \mu \mathrm{g}( \pm 0.7))$ accumulation. Analysis of the media from all groups revealed negligible levels of alkaline phosphatase activity (data not shown).

\section{Influence of exogenous TGF- $\beta 3$ and HP on gene expression and TGF- $\beta$ protein synthesis}

SDSCs responded to the addition of $10 \mathrm{ng} / \mathrm{mL}$ of TGF- $\beta 3$ with a greater than 19-fold increase in Sox 9 expression, 2,400-fold increase in Aggrecan expression and a 140,000fold increase in type II collagen expression following 14 days in FS conditions compared to day 0 control levels (Fig. $4 \mathrm{a}, \mathrm{b}, \mathrm{c}$ ). The addition of $1 \mathrm{ng} / \mathrm{mL}$ of TGF- $\beta 3$ resulted in a 1,200-fold (D14 FS: $1202.7( \pm 858.6) v s$. D0 FS: 0.92 $( \pm 0.04), p \leq 0.0001)$ increase in Aggrecan relative gene expression compared to day 0 control levels (Fig. 4b). No difference was observed for type I collagen with and without TGF- $\beta 3$ supplementation following 14 days in FS culture (Fig. 4d). Type X collagen and Indian Hedgehog were not expressed at day 0 . By day 14, the expression of type X collagen and Indian Hedgehog was 100 fold and 5 fold higher respectively in pellets supplemented with 10 $\mathrm{ng} / \mathrm{mL}$ compared to $1 \mathrm{ng} / \mathrm{mL}$ of TGF- $\beta 3$ (data not shown).

The application of HP had no significant effect on the expression of Sox9, Aggrecan and type II collagen in the absence of growth factor supplementation at day 14, but did lead to significant decrease in type I collagen gene expression (HP: $0.13( \pm 0.07) v s . \mathrm{FS}: 1.02( \pm 0.002), p \leq$ 0.01 ) (data not shown). Applying HP in the presence of $1 \mathrm{ng} /$ $\mathrm{mL}$ of TGF- $\beta 3$ resulted in a 3 -fold increase in the mRNA levels of Sox9 (HP: $3.19( \pm 0.45) v s$. FS: $1.21( \pm 0.09), p \leq$ 0.05) in comparison to FS controls (Fig. 5a). A similar trend was observed in the FPSCs group following the application of $\mathrm{HP}$ and $1 \mathrm{ng} / \mathrm{mL}$ of TGF- $\beta 3$ stimulation with a 3.5 -fold increase in Sox9 (HP: $3.53( \pm 0.45)$ vs. FS: $1.05( \pm 0.03), p \leq$ $0.1)$ relative gene expression in comparison to FS controls (data not shown). No significant difference was observed for the extracellular matrix specific genes aggrecan, type II collagen and type I collagen following the application of HP combined with either 1 or $10 \mathrm{ng} / \mathrm{mL}$ TGF- $\beta 3$ (Fig. $5 \mathrm{~b}, \mathrm{c}, \mathrm{d})$. Applying HP to SDSCs pellets in the presence of TGF- $\beta 3$ at 1 and $10 \mathrm{ng} / \mathrm{mL}$ also lead to decreases in the mRNA levels of the hypertrophic marker type X collagen and the developmental regulatory gene Indian Hedgehog (Fig. 5e, f).

Finally, in an attempt to explain the mechanism by which HP enhances chondrogenesis in SDSCs supplemented with $1 \mathrm{ng} / \mathrm{mL}$ of TGF- $\beta 3$, we explored if HP regulated the endogenous production of TGF- $\beta$ by measuring the concentration of TGF- $\beta 1$ and TGF- $\beta 3$ in the media of FS and HP pellets. The application of HP did not lead to additional endogenous production of TGF- $\beta 3$ by SDSCs already exogenously stimulated with TGF- $\beta 3$ (Fig. 6a). Exogenous stimulation of SDSCs with TGF- $\beta 3$ did result in endogenous production of TGF- $\beta 1$, but this 


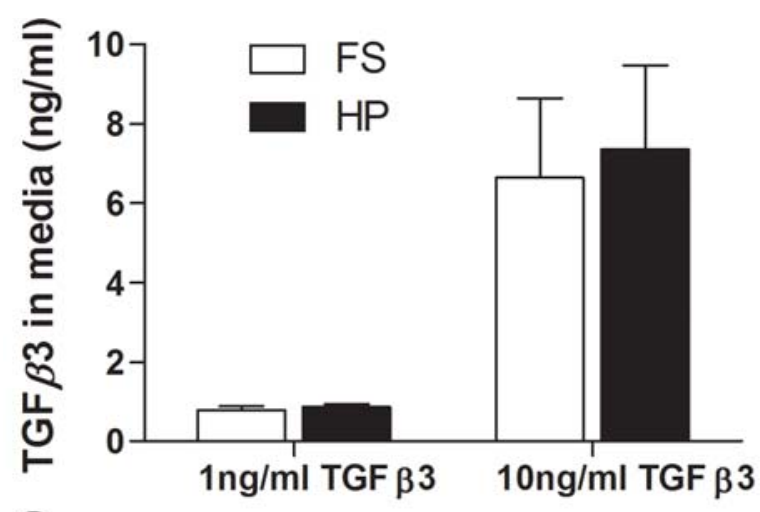

a
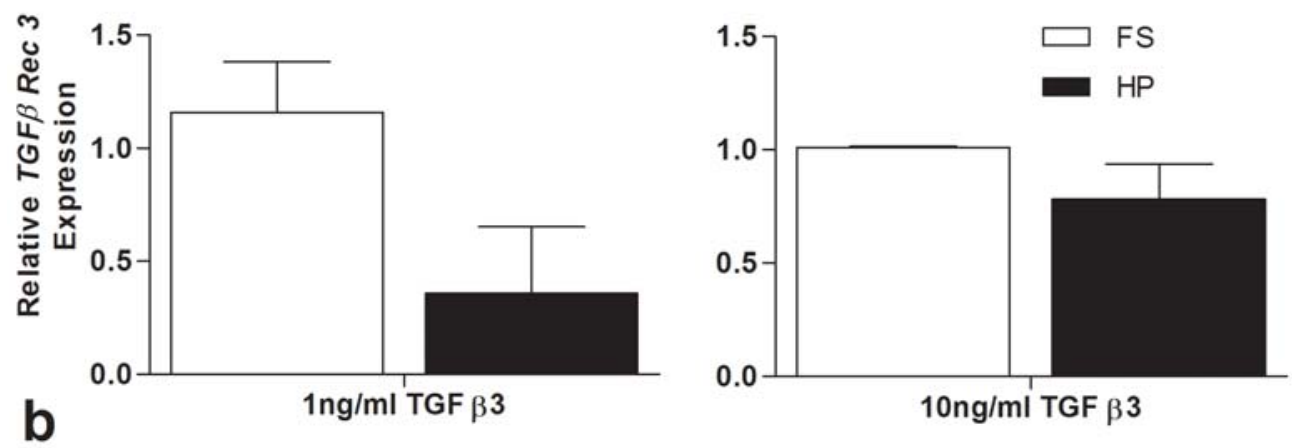

Fig. 6. (a) The influence of hydrostatic pressure on TGF- $\beta 3$ synthesis, as determined by measuring the concentration of TGF- $\beta 3$ in the media of pellets exogenously supplemented with either 1 or $10 \mathrm{ng} / \mathrm{mL}$ of TGF- $\beta 3$. (b) The influence of hydrostatic pressure on the expression of TGF- $\beta$ receptor 3 .

was not influenced by the application of HP (FS: $0.152 \pm$ $0.028 \mathrm{ng} / \mathrm{mL}$ TGF- $\beta 1$; HP: $0.156 \pm 0.037 \mathrm{ng} / \mathrm{mL}$ TGF- $\beta 1$; both groups supplemented with $1 \mathrm{ng} / \mathrm{mL}$ of TGF- $\beta 3$ ). Furthermore, HP did not significantly affect the mRNA levels of TGF- $\beta$ receptor 3 (Fig. 6b).

\section{Discussion}

Understanding how various environmental cues interact to regulate chondrogenesis of stem cells will be critical to the development of new regenerative medicine therapies for treating damaged and diseased articular cartilage. The objective of this study was to investigate the interaction between HP and TGF- $\beta 3$ in regulating the induction and maintenance of a chondrogenic phenotype in joint tissue derived stem cells. HP alone did not induce robust chondrogenesis of joint derived stem cells, however when applied with low concentrations of TGF- $\beta 3$, it acted synergistically to increase $S o x-9$ gene expression, promote sGAG synthesis and inhibit Indian Hedgehog and type $X$ collagen gene expression, the latter two being markers of pre-hypertrophy and terminal differentiation. At high magnitudes of TGF- $\beta 3$, HP had no additional synergistic effect on matrix synthesis, suggesting an upper limit on the stimulatory effects these two chondrogenic cues can have on matrix production, although it continued to act to suppress Indian Hedgehog and type X collagen gene expression. Interestingly, $\mathrm{CCs}$ responded differently to both TGF- $\beta 3$ stimulation and HP than joint tissue derived stem cells, with synthesis of sGAG and collagen inhibited at higher concentrations of TGF- $\beta 3$.

$\mathrm{HP}$ is one of the main mechanical stimuli exerted on articular cartilage and understanding its effects on stem cells and CCs is a central challenge in the field of articular cartilage tissue engineering and regeneration (Elder and Athanasiou, 2009). The loading regime chosen for this study was based on previous reports demonstrating that $10 \mathrm{MPa}$ of $\mathrm{HP}$ applied for $4 \mathrm{~h}$ daily at a frequency of $1 \mathrm{~Hz}$ enhanced chondrogenesis (Angele et al., 2003; Ikenoue et al., 2003; Miyanishi et al., 2006b). Exposure to $10 \mathrm{MPa}$ of HP influenced the organisation of the tissue, resulting in the formation of a more homogenous pellet. A similar observation has been reported using human bone marrow MSCs, where pellets exposed to $10 \mathrm{MPa}$ of HP exhibited a more compact and uniform structure than FS controls (Miyanishi et al., 2006a; Miyanishi et al., 2006b). Such alterations in the distribution of extracellular matrix components might be expected to lead to improvements in apparent construct mechanical functionality (Kelly and Prendergast, 2004) should the use of HP be extended to engineering cartilaginous grafts using scaffolds seeded with joint tissue derived MSCs (Meyer et al., 2011). 
Chondrocytes and joint tissue derived stem cells were found to differentially respond to altered TGF- $\beta 3$ concentrations. Johnstone et al. evaluated the effect of different concentrations of TGF- $\beta$ ( 0.5 to $10 \mathrm{ng} / \mathrm{mL})$ on bone marrow derived MSCs, concluding that lowering the TGF- $\beta$ concentration decreased their chondrogenic potential (Johnstone et al., 1998). A similar response to TGF- $\beta 3$ stimulation was observed in this study for joint tissue derived stem cells. FPSCs and SDSCs responded similarly to TGF- $\beta 3$ stimulation, corroborating previous reports where these two stem cell sources demonstrate a comparable level of chondrogenesis in response to cytokine stimulation (Mochizuki et al., 2006; Marsano et al., 2007). Interestingly when CCs were supplemented with higher concentrations of TGF- $\beta 3$, lower levels of sGAG and collagen accumulation were observed, which has also been reported for bovine CCs where supplementation with $10 \mathrm{ng} / \mathrm{mL}$ of TGF- $\beta 3$ was observed to suppress chondrogenesis (Erickson et al., 2011). This suppression of CCs chondrogenesis at high concentrations of TGF- $\beta 3$ was partially overcome when cells were subjected to HP. It is possible that $\mathrm{HP}$ is activating an alternative pathway to that of TGF- $\beta 3$ stimulation, one that acts independently or perhaps cross-talks intracellularly, or alternatively that HP is directly influencing TGF- $\beta$ signalling, although the results of this study do not provide any support for the hypothesis that HP regulates TGF- $\beta$ signalling in SDSCs. It has been suggested that HP can directly affect the conformation of transmembrane proteins (Kornblatt and Kornblatt, 2002; Elder and Athanasiou, 2009), raising the possibility that such extrinsic mechanical loading can physically alter TGF- $\beta$ receptors on the cell surface, and hence their binding affinity for TGF- $\beta 3$.

$\mathrm{HP}$, in the absence of TGF- $\beta 3$, did not appear to induce robust chondrogenesis of joint derived stem cells. In the case of bone marrow derived MSCs, some uncertainty exists in the literature as to the ability of HP to induce chondrogenesis in the absence of growth factors. Some report that HP has little or no effect on chondrogenic gene expression and matrix production (Zeiter et al., 2009), while others report increases in Sox-9, type II collagen and aggrecan gene expression but no increase in pellet wet weight due to loading (Miyanishi et al., 2006b). HP has also been shown to promote Sox-9 gene expression and protein production in SDSCs (Sakao et al., 2008; Wu et al., 2008), although such increases in the expression of regulatory genes due to HP does not necessarily lead to changes in the expression of aggrecan and type II collagen (Finger et al., 2007). In the present study we found that $\mathrm{HP}$ acts synergistically with low concentrations of TGF- $\beta 3$ to enhance chondrogenesis of joint tissue derived MSCs, as evidenced by a 3 -fold increase in Sox 9 expression and enhanced sGAG synthesis. As both biochemical and biophysical stimuli are present within the in vivo joint environment, further work is necessary to fully understand how these various cues interact to regulate stem cell fate.

In agreement with previous studies (Zeiter et al., 2009), we also observed that HP had no beneficial effect on cartilage-specific matrix production when stem cells were supplemented with $10 \mathrm{ng} / \mathrm{mL}$ of TGF- $\beta 3$. In contrast, a number of other studies have reported a synergistic effect for bone marrow MSCs supplemented with $10 \mathrm{ng} / \mathrm{mL}$ of TGF- $\beta 3$ (Miyanishi et al., 2006b; Wagner et al., 2008). Similar results have been observed for adipose derived stem cells (Ogawa et al., 2009). Given that synovial fibroblasts have been shown to produce TGF- $\beta$ when subjected to HP (Wu et al., 2008), we initially hypothesised that HP would exert its effects on joint tissue derived stem cells, at least in part, via this pathway. If this were the case, it might explain why HP only enhances chondrogenesis at lower concentrations of TGF- $\beta$, with the additional signal provided by HP being lost when saturation levels of TGF- $\beta$ are present. Previous studies have demonstrated that mechanical loading can enhance chondrogenesis of human bone marrow derived MSCs, which was promoted through the TGF pathway by up-regulating TGF gene expression and protein synthesis (Li et al., 2010). However, the results of this study do not provide evidence to support the hypothesis that HP influences TGF- $\beta$ synthesis in SDSCs, suggesting instead that it may act to regulate other signalling pathways involved in chondrogenesis of SDSCs. It has recently been demonstrated that the primary cilium is involved in signal transduction in response to hydrostatic compressive loading of growth plate chondrocytes (Shao et al., 2011). Given that the primary cilium is known to act as a mechanosensory organelle in numerous orthopaedic cells (Malone et al., 2007; Kwon et al., 2010; Hoey et al., 2011; Shao et al., 2011; Hoey et al., 2012), it is possible that HP exerts its effects on joint tissue derived stem cells through any one of numerous signalling pathways (e.g. Hedgehog, Wnt) that acts through the primary cilia.

It has been demonstrated that cartilaginous tissues engineered using SDSCs and FPSCs do not form stable cartilage following subcutaneous implantation (De Bari et al., 2004; Marsano et al., 2007; Dickhut et al., 2009). A major difference between the ectopic and orthotopic environment is the absence of mechanical signals such as HP, which may play a key role in achieving a type $\mathrm{X}$ collagen negative permanent cartilage phenotype (Steck et al., 2009). Joint loading has been shown to be an essential requirement for the homeostasis of normal articular cartilage (Palmoski et al., 1980; Kiviranta et al., 1987) and definition of articular tissues during development (Nowlan et al., 2010; Roddy et al., 2011). As chondrogenically primed bone marrow MSCs proceed to terminal differentiation, they express type $X$ collagen (Winter et al., 2003) and alkaline phosphatase (Pelttari et al., 2006), indicative of a hypertrophic phenotype (Dickhut et al., 2009). SDSCs have been shown to deposit similar levels of type $\mathrm{X}$ collagen to bone marrow and adipose derived stem cells after 5 weeks of chondrogenic induction in vitro (Dickhut et al., 2009), although they have a reduced tendency to undergo ectopic calcification, instead undergoing fibrous degeneration or complete degeneration. The hypertrophic markers analysed in this study: Indian hedgehog, which is expressed in the pre-hypertrophic zone during bone development (Kronenberg, 2003; Day and Yang, 2008) and type X collagen, a marker of the terminally differentiated (hypertrophic) chondrocyte phenotype, were both down-regulated due to the application of HP; suggesting that mechanical signals play a key role in the formation of a permanent or stable chondrocyte phenotype. 
Further support for such a hypothesis can be found in the results of previous studies demonstrating that HP downregulates the expression of $M M P-13$, a proteolytic enzyme in hypertrophic cartilage required for vascularisation of calcified cartilage (Wong et al., 2003). Given that our finding that HP, in the absence of TGF- $\beta$ stimulation, had little effect on cartilage-specific matrix accumulation, but that it did suppress the expression of genes associated with hypertrophy, regardless of the concentration of TGF- $\beta 3$, provides support for the idea that HP may play a more important role in the maintenance rather than the induction of a chondrogenic phenotype in joint derived stem cells. Mechanobiological models have previously suggested that hydrostatic pressure could inhibit endochondral ossification during skeletal regeneration (Carter et al., 1998), and here we provide experimental data in support of this hypothesis. In vivo, hydrostatic pressure may interact with the local oxygen environment (Sheehy et al., 2011) to regulate endochondral ossification.

A possible limitation of the study is the use of stem cells and chondrocytes isolated from skeletally immature pigs. Pigs share an underlying genetic and physiological similarity to humans (Vacanti et al., 2005), and it has been suggested that they may provide a useful animal model system to evaluate tissue engineering strategies (Ringe et al., 2002). Another limitation of the study is that we did not directly explore if joint tissue derived stem cells display a donor dependant response to HP or if the passage number of the cells makes a difference to their response to mechanical stimulation. We accept that the number of passages (Wiseman et al., 2004; Das et al., 2008) and some donor dependant response of joint tissue derived stem cells to biochemical and biophysical stimuli is highly likely, although this was not the primary question being addressed as part of this study

In conclusion, this study demonstrates that HP and TGF- $\beta 3$ interact to regulate chondrogenesis of joint tissue derived stem cells. The data demonstrates that HP can act synergistically with low concentrations of TGF- $\beta 3$ to up-regulate Sox 9 expression and the synthesis of cartilage-specific matrix molecules. Furthermore, HP acts to down-regulate the expression of genes associated with pre-hypertrophy and terminal differentiation (Indian hedgehog and type X collagen). In the context of stem cell based therapies for articular cartilage repair, the results of this study demonstrate the importance of considering how both biochemical and biophysical joint specific environmental factors might interact to regulate not only the initiation of chondrogenesis, but also the development of a stable cartilage repair tissue.

\section{Acknowledgements}

This work was supported by the Science Foundation Ireland under the President of Ireland Young Researcher Award (Grant No: SFI/08/YI5/B1336), the European Research Council starter grant (Stem Repair-Project \#258463) and the Trinity College Innovation Bursary. We would like to acknowledge the contribution of Tariq Mesallati to the preparation of this manuscript.

\section{References}

Angele P, Yoo JU, Smith C, Mansour J, Jepsen KJ, Nerlich M, Johnstone B (2003) Cyclic hydrostatic pressure enhances the chondrogenic phenotype of human mesenchymal progenitor cells differentiated in vitro. $\mathrm{J}$ Orthop Res 21: 451-457.

Buckley CT, Vinardell T, Kelly DJ (2010a) Oxygen tension differentially regulates the functional properties of cartilaginous tissues engineered from infrapatellar fat pad derived MSCs and articular chondrocytes. Osteoarthritis Cartilage 18: 1345-1354.

Buckley CT, Vinardell T, Thorpe SD, Haugh MG, Jones E, McGonagle D, Kelly DJ (2010b) Functional properties of cartilaginous tissues engineered from infrapatellar fat pad-derived mesenchymal stem cells. J Biomech 43: 920 926.

Buckwalter JA (1998) Articular cartilage: injuries and potential for healing. J Orthop Sports Phys Ther 28: 192202.

Carter DR, Beaupre GS, Giori NJ, Helms JA (1998) Mechanobiology of skeletal regeneration. Clin Orthop Relat Res (355 Suppl): S41-55.

Das RHJ, Jahr H, Verhaar JAN, van der Linden JC, van Osch GJVM, Weinans H (2008) In vitro expansion affects the response of chondrocytes to mechanical stimulation. Osteoarthritis Cartilage 16: 385-391.

Day TF, Yang Y (2008) Wnt and hedgehog signaling pathways in bone development. J Bone Joint Surg Am 90 Suppl 1: 19-24.

De Bari C, Dell'Accio F, Tylzanowski P, Luyten FP (2001) Multipotent mesenchymal stem cells from adult human synovial membrane. Arthritis Rheum 44: 19281942.

De Bari C, Dell'Accio F, Luyten FP (2004) Failure of in vitro-differentiated mesenchymal stem cells from the synovial membrane to form ectopic stable cartilage in vivo. Arthritis Rheum 50: 142-150.

Dickhut A, Pelttari K, Janicki P, Wagner W, Eckstein V, Egermann M, Richter W (2009) Calcification or dedifferentiation: requirement to lock mesenchymal stem cells in a desired differentiation stage. J Cell Physiol 219: 219-226.

Dragoo JL, Samimi B, Zhu M, Hame SL, Thomas BJ, Lieberman JR, Hedrick MH, Benhaim P (2003) Tissueengineered cartilage and bone using stem cells from human infrapatellar fat pads. J Bone Joint Surg Br 85: 740-747.

Elder BD, Athanasiou KA (2008) Synergistic and additive effects of hydrostatic pressure and growth factors on tissue formation. PLoS One 3: e2341.

Elder BD, Athanasiou KA (2009) Hydrostatic pressure in articular cartilage tissue engineering: from chondrocytes to tissue regeneration. Tissue Eng Part B Rev 15: 43-53.

Elder SH, Sanders SW, McCulley WR, Marr ML, Shim JW, Hasty KA (2006) Chondrocyte response to cyclic hydrostatic pressure in alginate versus pellet culture. J Orthop Res 24: 740-747.

English A, Jones EA, Corscadden D, Henshaw K, Chapman T, Emery P, McGonagle D (2007) A comparative assessment of cartilage and joint fat pad as a potential source of cells for autologous therapy development in knee osteoarthritis. Rheumatol (Oxford) 46: 1676-1683. 
Erickson IE, Van Veen SC, Sengupta S, Kestle SR, Mauck RL (2011) Cartilage matrix formation by bovine mesenchymal stem cells in three-dimensional culture is age-dependent. Clin Orthopaed Rel Res 469: 2744-2753.

Finger AR, Sargent CY, Dulaney KO, Bernacki SH, Loboa EG (2007) Differential effects on messenger ribonucleic acid expression by bone marrow-derived human mesenchymal stem cells seeded in agarose constructs due to ramped and steady applications of cyclic hydrostatic pressure. Tissue Eng 13: 1151-1158.

Hildner F, Albrecht C, Gabriel C, Redl H, van Griensven M (2011) State of the art and future perspectives of articular cartilage regeneration: A focus on adipose-derived stem cells and platelet-derived products. J Tissue Eng Regen Med 5: e36-e51.

Hoey DA, Kelly DJ, Jacobs CR (2011) A role for the primary cilium in paracrine signaling between mechanically stimulated osteocytes and mesenchymal stem cells. Biochem Biophys Res Commun 412: 182-187.

Hoey DA, Downs ME, Jacobs CR (2012) The mechanics of the primary cilium: An intricate structure with complex function. J Biomech 45: 17-26.

Ignat'eva NY, Danilov NA, Averkiev SV, Obrezkova MV, Lunin VV, Sobol EN (2007) Determination of hydroxyproline in tissues and the evaluation of the collagen content of the tissues. J Anal Chem 62: 51-57.

Ikenoue T, Trindade MC, Lee MS, Lin EY, Schurman DJ, Goodman SB, Smith RL (2003) Mechanoregulation of human articular chondrocyte aggrecan and type II collagen expression by intermittent hydrostatic pressure in vitro. J Orthop Res 21: 110-116.

Johnstone B, Hering TM, Caplan AI, Goldberg VM, Yoo JU (1998) In vitro chondrogenesis of bone marrowderived mesenchymal progenitor cells. Exp Cell Res 238: 265-272.

Kafienah W, Sims TJ (2004) Biochemical methods for the analysis of tissue-engineered cartilage. Methods Mol Biol 238: 217-230.

Kelly DJ, Jacobs CR (2010) The role of mechanical signals in regulating chondrogenesis and osteogenesis of mesenchymal stem cells. Birth Defects Res C Embryo Today 90: 75-85.

Kelly DJ, Prendergast PJ (2004) Effect of a degraded core on the mechanical behaviour of tissue-engineered cartilage constructs: a poro-elastic finite element analysis. Med Biol Eng Comput 42: 9-13.

Khan WS, Adesida AB, Hardingham TE (2007) Hypoxic conditions increase hypoxia-inducible transcription factor 2alpha and enhance chondrogenesis in stem cells from the infrapatellar fat pad of osteoarthritis patients. Arthritis Res Ther 9: R55.

Khan WS, Tew SR, Adesida AB, Hardingham TE (2008) Human infrapatellar fat pad-derived stem cells express the pericyte marker $3 \mathrm{G} 5$ and show enhanced chondrogenesis after expansion in fibroblast growth factor-2. Arthritis Res Ther 10: R74.

Kiviranta I, Jurvelin J, Tammi M, Saamanen AM, Helminen HJ (1987) Weight bearing controls glycosaminoglycan concentration and articular cartilage thickness in the knee joints of young beagle dogs. Arthritis Rheum 30: 801-809.
Kornblatt JA, Kornblatt MJ (2002) The effects of osmotic and hydrostatic pressures on macromolecular systems. Biochim Biophys Acta 1595: 30-47.

Kronenberg HM (2003) Developmental regulation of the growth plate. Nature 423: 332-336.

Kwon RY, Temiyasathit S, Tummala P, Quah CC, Jacobs CR (2010) Primary cilium-dependent mechanosensing is mediated by adenylyl cyclase 6 and cyclic AMP in bone cells. FASEB J 24: 2859-2868.

Lee SY, Nakagawa T, Reddi AH (2008) Induction of chondrogenesis and expression of superficial zone protein (SZP)/lubricin by mesenchymal progenitors in the infrapatellar fat pad of the knee joint treated with TGFbeta1 and BMP-7. Biochem Biophys Res Commun 376: 148-153.

Li Z, Kupcsik L, Yao SJ, Alini M, Stoddart MJ (2010) Mechanical load modulates chondrogenesis of human mesenchymal stem cells through the TGF-beta pathway. J Cell Mol Med 14:1338-1346.

Livak KJ, Schmittgen TD (2001) Analysis of relative gene expression data using real-time quantitative PCR and the 2(-Delta Delta C(T)) Method. Methods 25:402-408.

Loboa EG, Beaupre GS, Carter DR (2001) Mechanobiology of initial pseudarthrosis formation with oblique fractures. J Orthop Res 19:1067-1072.

Malone AMD, Anderson CT, Tummala P, Kwon RY, Johnston TR, Stearns T, Jacobs CR (2007) Primary cilia mediate mechanosensing in bone cells by a calciumindependent mechanism. Proc Natl Acad Sci USA 104: 13325-13330.

Marsano A, Millward-Sadler SJ, Salter DM, Adesida A, Hardingham T, Tognana E, Kon E, Chiari-Grisar C, Nehrer S, Jakob M, Martin I (2007) Differential cartilaginous tissue formation by human synovial membrane, fat pad, meniscus cells and articular chondrocytes. Osteoarthritis Cartilage 15: 48-58.

Meyer EG, Buckley CT, Steward AJ, Kelly DJ (2011) The effect of cyclic hydrostatic pressure on the functional development of cartilaginous tissues engineered using bone marrow derived mesenchymal stem cells. J Mech Behaviour Biomed Mater DOI: 10.1016/j.jmbbm.2011.04.012.

Miyanishi K, Trindade MC, Lindsey DP, Beaupre GS, Carter DR, Goodman SB, Schurman DJ, Smith RL (2006a) Dose- and time-dependent effects of cyclic hydrostatic pressure on transforming growth factor-beta3-induced chondrogenesis by adult human mesenchymal stem cells in vitro. Tissue Eng 12: 2253-2262.

Miyanishi K, Trindade MC, Lindsey DP, Beaupre GS, Carter DR, Goodman SB, Schurman DJ, Smith RL (2006b) Effects of hydrostatic pressure and transforming growth factor-beta 3 on adult human mesenchymal stem cell chondrogenesis in vitro. Tissue Eng 12: 1419-1428.

Mochizuki T, Muneta T, Sakaguchi Y, Nimura A, Yokoyama A, Koga H, Sekiya I (2006) Higher chondrogenic potential of fibrous synovium- and adipose synovium-derived cells compared with subcutaneous fatderived cells: distinguishing properties of mesenchymal stem cells in humans. Arthritis Rheum 54: 843-853.

Nowlan NC, Bourdon C, Dumas G, Tajbakhsh S, Prendergast PJ, Murphy P (2010) Developing bones are 
differentially affected by compromised skeletal muscle formation. Bone 46: 1275-1285.

Ogawa R, Mizuno S, Murphy GF, Orgill DP (2009) The effect of hydrostatic pressure on three-dimensional chondroinduction of human adipose-derived stem cells. Tissue Eng Part A 15: 2937-2945.

Palmoski MJ, Colyer RA, Brandt KD (1980) Joint motion in the absence of normal loading does not maintain normal articular cartilage. Arthritis Rheum 23: 325-334.

Parkkinen JJ, Ikonen J, Lammi MJ, Laakkonen J, Tammi M, Helminen HJ (1993) Effects of cyclic hydrostatic pressure on proteoglycan synthesis in cultured chondrocytes and articular cartilage explants. Arch Biochem Biophys 300: 458-465.

Pei M, He F, Kish VL, Vunjak-Novakovic G (2008a) Engineering of functional cartilage tissue using stem cells from synovial lining: a preliminary study. Clin Orthop Relat Res 466: 1880-1889.

Pei M, He F, Vunjak-Novakovic G (2008b) Synoviumderived stem cell-based chondrogenesis. Differentiation 76: 1044-1056.

Pelttari K, Winter A, Steck E, Goetzke K, Hennig T, Ochs BG, Aigner T, Richter W (2006) Premature induction of hypertrophy during in vitro chondrogenesis of human mesenchymal stem cells correlates with calcification and vascular invasion after ectopic transplantation in SCID mice. Arthritis Rheum 54: 3254-3266.

Pittenger MF, Mackay AM, Beck SC, Jaiswal RK, Douglas R, Mosca JD, Moorman MA, Simonetti DW, Craig S, Marshak DR (1999) Multilineage potential of adult human mesenchymal stem cells. Science 284: 143-147.

Ringe J, Kaps C, Schmitt B, Buscher K, Bartel J, Smolian H, Schultz O, Burmester GR, Haupl T, Sittinger M (2002) Porcine mesenchymal stem cells. Induction of distinct mesenchymal cell lineages. Cell Tissue Res 307: 321-327.

Roddy KA, Prendergast PJ, Murphy P (2011) Mechanical influences on morphogenesis of the knee joint revealed through morphological, molecular and computational analysis of immobilised embryos. PLoS One 6: e17526.

Sakao K, Takahashi KA, Arai Y, Inoue A, Tonomura H, Saito M, Yamamoto T, Kanamura N, Imanishi J, Mazda O, Kubo T (2008) Induction of chondrogenic phenotype in synovium-derived progenitor cells by intermittent hydrostatic pressure. Osteoarthritis Cartilage 16: 805-814.

Segawa Y, Muneta T, Makino H, Nimura A, Mochizuki T, Ju Y J, Ezura Y, Umezawa A, Sekiya I (2009) Mesenchymal stem cells derived from synovium, meniscus, anterior cruciate ligament, and articular chondrocytes share similar gene expression profiles. J Orthopaed Res 27: 435 441.

Shao YY, Wang L, Welter JF, Ballock RT (2011) Primary cilia modulate Ihh signal transduction in response to hydrostatic loading of growth plate chondrocytes. Bone 50: 79-84.

Sheehy EJ, Buckley CT, Kelly DJ (2011) Oxygen tension regulates the osteogenic, chondrogenic and endochondral phenotype of bone marrow derived mesenchymal stem cells. Biochem Biophys Res Commun, in press.

Steck E, Fischer J, Lorenz H, Gotterbarm T, Jung M, Richter W (2009) Mesenchymal stem cell differentiation in an experimental cartilage defect: restriction of hypertrophy to bone-close neocartilage. Stem Cells Dev 18: 969-978.

Stoddart MJ, Grad S, Eglin D, Alini M (2009) Cells and biomaterials in cartilage tissue engineering. Regen Med 4: 81-98.

Toyoda T, Seedhom BB, Kirkham J, Bonass WA (2003a) Upregulation of aggrecan and type II collagen mRNA expression in bovine chondrocytes by the application of hydrostatic pressure. Biorheology 40: 79-85.

Toyoda T, Seedhom BB, Yao JQ, Kirkham J, Brookes S, Bonass WA (2003b) Hydrostatic pressure modulates proteoglycan metabolism in chondrocytes seeded in agarose. Arthritis Rheum 48: 2865-2872.

Vacanti V, Kong E, Suzuki G, Sato K, Canty JM, Lee T (2005) Phenotypic changes of adult porcine mesenchymal stem cells induced by prolonged passaging in culture. J Cell Physiol 205: 194-201.

Vinardell T, Buckley CT, Thorpe SD, Kelly DJ (2011) Composition-function relations of cartilaginous tissues engineered from chondrocytes and mesenchymal stem cells isolated from bone marrow and infrapatellar fat pad. J Tissue Eng Regen Med 5: 673-683.

Wagner DR, Lindsey DP, Li KW, Tummala P, Chandran SE, Smith RL, Longaker MT, Carter DR, Beaupre GS (2008) Hydrostatic pressure enhances chondrogenic differentiation of human bone marrow stromal cells in osteochondrogenic medium. Ann Biomed Eng 36: 813820.

Wickham MQ, Erickson GR, Gimble JM, Vail TP, Guilak F (2003) Multipotent stromal cells derived from the infrapatellar fat pad of the knee. Clin Orthop Relat Res 412: 196-212.

Winter A, Breit S, Parsch D, Benz K, Steck E, Hauner H, Weber RM, Ewerbeck V, Richter W (2003) Cartilagelike gene expression in differentiated human stem cell spheroids: a comparison of bone marrow-derived and adipose tissue-derived stromal cells. Arthritis Rheum 48: 418-429.

Wiseman M, Bader DL, Reisler T, Lee DA (2004) Passage in monolayer influences the response of chondrocytes to dynamic compression. Biorheology 41: 283-298.

Wong M, Siegrist M, Goodwin K (2003) Cyclic tensile strain and cyclic hydrostatic pressure differentially regulate expression of hypertrophic markers in primary chondrocytes. Bone 33: 685-693.

Wu MJ, Gu ZY, Sun W (2008) Effects of hydrostatic pressure on cytoskeleton and BMP-2, TGF-beta, SOX-9 production in rat temporomandibular synovial fibroblasts. Osteoarthritis Cartilage 16: 41-47.

Zeiter S, Lezuo P, Ito K (2009) Effect of TGF beta1, BMP-2 and hydraulic pressure on chondrogenic differentiation of bovine bone marrow mesenchymal stromal cells. Biorheology 46: 45-55. 


\section{Discussion with Reviewers}

Reviewer I: You state in Material and Methods that "at each media exchange samples of media were taken for analysis of ALP, sGAG and total collagen ...." To what did you normalise the values measured in the media samples taken at each time point or media exchange - as digestions of the samples was only done at day 0 and day 14 ?

Authors: A sample of media was taken at each media exchange and then the amount GAG and collagen and ALP activity was analysed separately and normalised by the number of pellets, i.e., the average release per pellet was determined.

Reviewer I: Please comment on the differences in cellular composition of synovial membrane and fat tissue in comparison to cartilage.

Authors: The synovial membrane is a vascular connective tissue that lines the inner surface of the joint capsule and articulates with itself or with the margins of the articular cartilage (Radin, 2001). The synovium is composed of an inner layer (intima) and a deep layer (subintima). Within the inner layer are 4 types of synovial lining cells that overlap one in another in 2 or 3 layers: macrophages, fibroblasts, endothelial cells and mastocysts. The deep layer is composed of adipose and synovial cells (Dewire and Einhorn, 2001).

Intra-articular fat pads are a feature of some joints. They are composed of adipocytes and adipose connective tissue containing collagen and glycosaminoglycans. Its surface is covered with synovial membrane and its role is to facilitate the distribution of synovial fluid within the joint and act as a cushion protecting exposed articular surfaces (Vahlensieck et al., 2002; Nakano et al., 2004).

Further commentary on the differences between SDSCs and FPSCs can be found in Mochizuki et al. (2006) (text reference).

Reviewer I: What is the percentage of cells that can really be considered as stem cells in these tissues?

Authors: A minimal amount of synovial tissue is required to extract the SMSCs successfully. Based on the CFU-F data obtained in our laboratory from 9 different porcine donors, approximately $2-4 \%$ of cells from these joint tissues are colony-forming, although it must be stated that this in itself cannot be used to state that this percentage of the population are true stem cells.

Reviewer I: How did the cell yield and expansion period differ for the three investigated tissues and did this influence differentiation capacity of the cells?

Authors: CCs were expanded to passage one (7 population doubling) and stem cells to passage two (14-15 population doublings for each stem cell source). Because CCs are known to de-dedifferentiate in monolayer culture (Benya et al., 1978), we aimed to minimise the number of population doublings for the CC group. As is well reported in the literature, expanding joint derived stem cells to passage 14 doesn't seem to affect their chondrogenic potential (De Bari et al., 2001; Mochizuki el al., 2006, text references; Sakaguchi et al., 2005, additional reference).
Reviewer I: Does this influence the responsivity of the cells to mechanical loading?

Authors: Das et al. (2008) (text reference) have shown that expansion alters the response of human chondrocytes to stretch. Therefore, the answer to the reviewer's question is yes, but in order to have the sufficient number of cells to perform the study we had to expand them.

Reviewer II: Would it be possible to investigate the isoforms TGF- $\beta 1$, TGF- $\beta 2$ and TGF- $\beta 3$ ? Does HP affect their expression differentially?

This is even more pertinent when considering of the studies referenced Miyanishi et al. (2006a,b) (text references) used TGF- $\beta 3$ (as in this study) whereas Zeiter et al. (2009) (text reference) used TGF- $\beta 1$. There are few papers investigating the differences of the various isoforms, and the fact that isoforms exist indicates they will have different effects. Is the response to HP one of them?

Authors: To address the reviewers comment, we analysed both TGF- $\beta 1$ and TGF- $\beta 3$ production in SMSCs in response to HP for the $1 \mathrm{ng} / \mathrm{mL}$ of TGF- $\beta 3$ arm of the study where this mechanical stimulus has been shown to enhance cartilage specific matrix synthesis. We found that while measurable levels of TGF- $\beta 1$ were found in the media, these values did not increase with the application of HP. Furthermore, HP did not influence the synthesis of TGF- $\beta 3$ or the expression of TGF- $\beta$ receptor 3 . Therefore, we were unable to provide evidence to support the hypothesis that HP exerts its influence on stem cell chondrogenesis by altering TGF- $\beta$ signalling.

Reviewer II: One interesting observation is that $\mathrm{IHH}$ is down-regulated. Does this translate into a change in protein levels? As can be seen from the authors' own data, the 2-3,000 fold increase in aggrecan mRNA only did not lead to the same level of sulphated GAG.

Authors: We did not measure IHH at the protein level. While HP led to decreases in type X gene expression, immunohistochemistry did not reveal any dramatic difference in type X collagen production. Therefore, our feeling is that while HP is impacting on the expression of these proteins at the gene level by day 14, noticeable differences in protein production will not be observed until later time points as stem cells proceed towards terminal differentiation.

Reviewer III: What was the baseline value from cells without exposure to TGF $\beta$ ?

Authors: Negligible amounts of sGAG were produced by stem cells not supplemented with TGF- $\beta 3$. It was therefore concluded that they did not undergo robust chondrogenesis and were not considered for further analysis.

Reviewer III: The authors conclude in their last sentence of the paper that their study has important results relevant to stem cell based therapies for articular cartilage. One assumes that they are meaning, in the main, for treating humans who will be at least skeletally mature, if not of a more advanced age. How do they think that their results, which have been carried out only on 4-month old pigs, might have been different if performed on skeletally 
mature individuals (with pigs attaining skeletal maturity at approximately 18 months of age)?

Authors: It has been demonstrated that cartilage matrix formation by MSCs in three-dimensional culture in response to TGF- $\beta$ stimulation is age-dependent (Erickson et al., 2011). Given that the response of MSCs to biochemical cues is age-dependent, it is reasonable to believe that the response of MSCs to mechanical signals will also be age-dependent. Further studies are required to explore this hypothesis.

\section{Additional References}

Benya PD, Padilla SR, Nimmi ME (1978) Independent regulation of collagen types by chondrocytes during the loss of differentiated function in culture. Cell 15: 13131321.

Dewire P, Einhorn TA (2001) The joint as an organ. In: Osteoarthritis: Diagnosis and Medical/Surgical Management (Moskowitz RW, Howell DS, Altman RD, Buckwalter JA, Goldberg VM, eds). W.B.Saunders, Philadelphia. 1: 49-68.
Erickson IE, Van Veen SC, Sengupta S, Kestle SR, Mauck RL (2011) Cartilage matrix formation by bovine mesenchymal stem cells in three-dimensional culture is age-dependent. Clinical Orthopaed Rel Res 469: 27442753.

Nakano T, Wang YW, Ozimek L, Sim JS (2004) Chemical composition of the infrapatellar fat pad of swine. J Anat 204: 301-306.

Radin EL (2001) Structure and function of joints. In: Arthritis and allied conditions. A textbook of rheumatology (Koopman WJ, ed). Lippincott Williams and Wilkins, Philadelphia. 1: 157-173.

Sakaguchi Y, Sekiya I, Yagishita K, Muneta T (2005) Comparison of human stem cells derived from various mesenchymal tissues: superiority of synovium as a cell source. Arthritis Rheum 52: 2521-2529.

Vahlensieck M, Linneborn G, Schild H, Schmidt HM (2002) Hoffa's recess: incidence, morphology and differential diagnosis of the globular-shaped cleft in the infrapatellar fat pad of the knee on MRI and cadaver dissections. Eur Radiol 12: 90-93. 